\title{
Can Local Comparative Judgements Justify Moderate Perfectionism?
}

\author{
Henrik D. Kugelberg ${ }^{1}$
}

Received: 18 December 2020 / Revised: 18 March 2021 / Accepted: 26 May 2021 /

Published online: 5 July 2021

(c) The Author(s) 2021

\begin{abstract}
A common objection to political liberalism is that since reasonable citizens agree that some ways of life are worse than others - for instance that the life of a drug addict is less worthwhile than the life of a person who spends her time with family and philosophy - political liberals must concede that the state can sometimes permissibly use perfectionist reasons. I argue in this paper that this challenge is mistaken, because the comparison only tells us something about relative, not absolute, value. And because the real question concerns what the right justificatory constituency looks like, not what counts as reasonable in some other sense, the implication is that perfectionists and political liberals could construct equally plausible idealised constituencies. This stalemate gives us reason to develop arguments in favour of our preferred justificatory constituency. We cannot view local comparative judgements in isolation.
\end{abstract}

Keywords Perfectionism · Political liberalism · Public justification · Public reason · Drugs

Political liberals argue that the state should not appeal to reasons that presuppose the truth of any particular conception of the good life when justifying political decisions, because reasonable citizens disagree about what a good life consists in. All reasonable citizens need to be able to appreciate the normative relevance of the reasons that public officials give for the laws and policies that apply to them. Reasons drawn from 'the good' are incompatible with this (Boettcher, 2004; Boettcher, 2019; Lister, 2018; Quong, 2014a; Schouten, 2019; Watson \& Hartley, 2018).

A common objection to this picture is that reasonable citizens actually do agree that some ways of life are better than others. It is said that all reasonable people surely must recognise that the life of a drug addict is less worthwhile than the life of a person with a good family who is interested in music and philosophy. Since there

Henrik D. Kugelberg

Henrik.kugelberg@politics.ox.ac.uk

1 Department of Politics and International Relations, University of Oxford, Oxford, UK 
is agreement on the weighting of this 'local comparative judgement', the argument goes, political liberals must concede that the state can sometimes legitimately rely on reasons drawn from the good when justifying policies. This is a moderate perfectionism, where some reasons that make limited assumptions about the truth of certain conceptions of the good life are permissible.

The challenge has been levelled numerous times. ${ }^{1}$ In fact, it is a standard feature of virtually all perfectionist internal critiques of political liberalism. Only in recent years, it has been employed by philosophers such as Timothy Fowler and Zofia Stemplowska (2015, 140-1), Cécile Laborde (2017, 99), Franz Mang (2013), and Andrew Lister (2014, 28-32). ${ }^{2}$ An early version comes from Joseph Chan (2000).

In this short paper, I argue that the challenge is based on two crucial mistakes. Comparing two ways of life cannot ground perfectionism, because the comparison in itself can only tell us something about relative, not absolute, value. Moreover, appealing to intuitions about reasonableness is the wrong way of settling the issue. The real question concerns what the right justificatory constituency looks like, not what counts as reasonable in some other sense.

Before I begin, let me emphasise that with this paper I do not wish to suggest that there are no routes available for moderate perfectionists to ground their theories of permissible state action. Indeed, there are many, and some of them might be more plausible. My claim is weaker. Those who wish to argue in favour of moderate perfectionism must do so without the local comparative judgements strategy. And a fruitful debate between perfectionists and anti-perfectionists must start in a discussion of what the constituency of people that laws should be justified to looks like.

\section{The Challenge}

Political liberals argue that since there is disagreement among reasonable people about what a good life consists in, state actions cannot be justified by appealing to reasons drawn from 'the good' (Quong, 2011, 37; see also Vallier, 2017, 177). In a very influential article, Joseph Chan puts pressure on this by suggesting that we can use 'local comparative judgements' to see that, when viewed in isolation, all reasonable points of view would agree that some ways of life are better than others. It is, in other words, possible to find instances where all reasonable moral points of view converge.

The comparison of the life of a drug addict and a family man, Chan (2000, 13-14) argues, is such a case. All reasonable people would agree that the life of the latter is better:

John... is wise, upright, talented in music and philosophy and has a good family and a few very good friends; Mark [is] a drug-addict, who spends all his

\footnotetext{
${ }^{1}$ I do not mean to say that the comparison of drug users and family lovers is the only version of the moderate perfectionist challenge. I deal with this widely used example in section 2 , but the discussion in sections 3 and 4 generalises to other versions as well.

${ }^{2}$ Even if Lister is careful to avoid many of the issues discussed below, he still relies on the strategy to make his argument.
} 
time chasing after elusive drug pleasures at the expense of all other goods. I think no reasonable person would dispute the judgement that John's way of life is more worthwhile than Mark's.

Chan suggests that this entails that political liberals must concede that it would be permissible for the state to justify policies with reasons based on this agreement.

Since Chan's initial argument, the example of the drug user has become a standard feature of virtually all perfectionist arguments challenging political liberalism on its own terms. For instance, Fowler and Stemplowska $(2015,140)$ argue that if no 'reasonable person with a plausible balance of values can believe... [a] drug-driven lifestyle to bebetter than... [the lifestyle of a family man],' it follows from Jonathan Quong's political liberalism that 'there could be some occasions when a state can legitimately act for perfectionist reasons'. Laborde $(2017,100)$ holds that if people 'broadly agree about the badness of addiction, it would seem to follow (on Quong's theory) that the state can permissibly appeal to this reason to justify its tax and health policies'. And Mang $(2013,302-3)$ points out that the statement 'hard-drug addiction is harmful to most, if not all, people' should be 'accepted beyond reasonable doubt', so the state's 'appeal to those judgments is compatible with Rawls's idea of legitimacy.'

Next, I show why this comparison cannot establish that political liberals should allow perfectionism.

\section{Of Drugs and Family Men: Comparing Two Ways of Life}

For the purposes of this paper, let us grant that many people would accept that John's life is better than Mark's. What kind of state action would this agreement, insofar as it exists, legitimise? I can think of two types of interventions that moderate perfectionist would suggest could be justified by drawing on the comparison: the state permissibly discouraging people from living like Mark and the state permissibly encouraging people to live like John. Are they right about this?

It is important to note that the state cannot promote or discourage a full life. Instead, it can only target some of the individual components that make up a given life. Policies to discourage Mark-ness might be things such as the criminalisation of drugs and information campaigns about the dangers of drug use. To encourage John-ness, we could imagine policies such as subsidies for the opera or tax breaks for families. The question, then, is whether appealing to the comparison can make such policies publicly justified.

Let us turn, first, to discouraging people from living like Mark. The first thing to say is that even if there is an overlapping consensus on the idea that John's way of life is preferable to Mark's, this agreement in itself is not based on the absolute disvalue of Mark's way of life. It only shows that his way of life is not preferable to John's. The comparison does not say anything about whether the overlapping consensus is on the idea that Mark's way of life is terrible or whether his way of life is simply worse than John's. Indeed, the very idea of a comparison points to the second interpretation: 'no reasonable person would dispute the judgement that John's way 
of life is more worthwhile than Mark's.' This is important, because the comparison, if it lacks explicit judgements about the absolute badness of the 'lowest ranked life' and the badness of its individual components, cannot justify political action to discourage people from living it. The comparison does not suffice to justify state action, because the agreement only establishes that Mark's way of life is worse than John's, not that Mark's life is bad and worth discouraging.

I grant that we might be justified in choosing to discourage people from living like Mark based solely on the comparison if we somehow were forced to make a binary choice between a policy that discouraged people from living like John and a policy that discouraged people from living like Mark. Under such circumstances, we should probably opt for the latter policy, given that most people would see John's way of life as better than Mark's. If so, it does not matter that the comparison cannot establish the absolute disvalue of Mark's life and its individual components. ${ }^{3}$

The problem, however, is that this is not the kind of choice that the state is faced with. It typically does not have to choose between only these two courses of action. The same goes for policies that would promote John's life. And, just as with Mark, we cannot know based on the comparison that John's life is good. It could simply be better than Mark's life. To allow relative value judgements in public justification would let us appeal to any way of life as good, as long as it is better than Mark's.

To see this, suppose that we compare Mark's life with Natalie's instead. Natalie does not have any close friends. She does not have a family, and she knows nothing about philosophy or classical music. However, she enjoys going to the church every Sunday. If it is true that Natalie's life is better than Mark's according to all reasonable moral points of view, does this entail that the state could permissibly promote church-going? I cannot see that it would. In much the same way, the comparison cannot show that we can promote the individual components of John's life.

The state does not only have the choice between promoting John's or Mark's life. It may just as well choose to promote an infinite range of other lives. For instance, it could promote some of the components necessary for Natalie's life instead. Or picture, for instance Nathan, who spends his Sundays playing video games. By allocating resources to promoting church-going - the thing that gives Natalie's life great value - we promote it over the components necessary for Mark's, John's and Nathan's lives. And by promoting John's classical music and philosophy, we are promoting the activities that he values over the activities valued by Natalie and Nathan. What grounds might we have for doing so? If John's life is better than Mark's, it does not imply that it is better than Nathan's or Natalie's. Consequently, it does not make sense to promote classical music, church-going, or video games, unless we know that either of these activities would make the lives of the people who currently do not engage in them valuable.

Here is another way of putting it. When Chan and others compare Mark and John, they are making a multivariate comparison. However, the desired conclusion that they try to establish is that it would be permissible to promote specific components or variables on one side of this comparison (for instance classical music

\footnotetext{
${ }^{3}$ I am grateful to an anonymous reviewer for helpful comments on this point.
} 
or philosophy). ${ }^{4}$ This is quite a jump. Even if, on a multivariate analysis, we see that one way of life is better than another, it does not give us reason to promote any one specific variable that is a part of that life, because the promotion will be at the expense of components of other ways of life that also might be good. To put it crudely: money spent on a new music hall means less money for art galleries, football stadiums, housing subsidies, and so on.

We could even grant that for a specific multivariate comparison between a terrible and a less terrible life, many reasonable people would converge on the idea that the life that is less terrible is preferable. Even so, this to me looks as much too insignificant an achievement for passing the test of public justification, or for allowing that reasons based on this agreement are public reasons. Analogously, it would be like accepting that a reason is a public reason simply because it is a better reason than a horrible reason. Compare:

$\mathrm{R}_{1}$ : This law is what the devil wants.

$\mathrm{R}_{2}$ : This law maximises hedonist utility.

Even if most reasonable points of view would agree that $R_{2}$ is a better justification than $\mathrm{R}_{1}$, this does not automatically make it a public reason, since not all reasonable people would believe that it is a good, sufficient, or normatively relevant reason. Not all reasonable citizens are hedonist utilitarians, but most reasonable citizens are (presumably) not Satanists. ${ }^{5}$ Hence, at most, we can get an overlapping consensus on the fact that $R_{1}$ is a worse reason than $R_{2}$. But $R_{2}$ might also be a bad reason. Perhaps, it is just slightly less bad than $\mathrm{R}_{1}$. A lawmaker who says 'maximising hedonist utility is better than following the will of the devil, therefore we should enact this law that maximises hedonist utility' has not provided public reasons. Similarly, saying: 'living a life with family, friends, and philosophy is better than chasing elusive drug pleasure, therefore we should enact this law that encourages family life (or that discourages drug use)' is also not to provide public reasons.

For the local comparative judgement strategy to work, we need to establish that there are good ways of life to subsidise, even at the expense of other good ways of life, and bad ways of life to discourage. Such thick agreements will be much more difficult to find. Trying to justify perfectionist policy on the basis of the local comparison is therefore to commit a fallacy of reasoning. Including John in the description of Mark is merely a rhetorical distraction.

Presumably, some people would object to this description. They might suggest that the case of Mark and John is an instance where it just is intuitively obvious that John's life is good, and that Mark's life is bad. On this reading, the comparison is not really that important. It is just a tool for making these intuitively obvious facts clearer for all to see. It is a strategy for emphasising that reasonable people surely just would recognise that Mark's life, and its individual components, are bad and worth discouraging, and that John's way of life is good and worth promoting.

\footnotetext{
${ }^{4}$ Detailed comments from an anonymous reviewer were invaluable for clarifying what, precisely, is at stake here.

5 Stuart White has made me aware of the existence of reasonable Satanists. Let us suppose that the Satanists I am referring to are unreasonable (Laycock, 2020).
} 
The problem with this, however, is that on many accounts of public justification, the fact that reasonable people tend to agree to something is not the relevant test. Instead, all possible reasonable people must agree to it. I show why this is so in the next section.

\section{Justificatory Constituencies}

It is impossible to determine whether there are perfectionist ideas that reasonable people share without a wider theory of public justification. To be able to settle the question, we need to know what we take the reasonable points of views to be. Is a religious group arguing that John's life lacks spirituality reasonable? Is it reasonable to say that philosophy is a pointless endeavour? Are adrenaline junkies unreasonable in saying that the only life worth living is one with constant kicks? Should policies be justified to these groups? If so, there is no genuine agreement on the goodness of John's way of life. Or are all views that deny the absolute value of John's way of life and its individual components unreasonable? ${ }^{6}$

The moderate perfectionist challenge cannot be levelled against a specific theory of public justification without a close engagement with its premises. I will illustrate this with Quong's theory since it is a frequent target, but similar things can be said for many other accounts.

On Quong's view, disagreements about justice and the good are of a different kind. Disagreement about justice is justificatory whereas disagreement about the good 'almost certainly' is foundational. When there is foundational disagreement, there is no 'deeper standard of justification that... [those who disagree] accept that could serve as the basis for adjudicating their dispute' (Quong, 2011, 193). Justificatory disagreement, on the other hand, means that we share the same view of 'what counts as a good reason when debating about the principles of justice,' (Quong, $2011,206)$ and that the disagreeing parties can 'accept the other's argument as a reasonable example of a public justification, although they do not believe it is the most reasonable public justification available' (Quong, 2011, 212). State action is legitimate if it is compatible with justificatory disagreement, but not with foundational disagreement.

Opponents levelling the perfectionist challenge against Quong's particular version of political liberalism need to show that not all disagreement about the good is foundational. They have tried to do so by suggesting that reasonable people would agree that a life of drug addiction is bad. Hence, if a reason based on this is used in favour of a particular drug policy, all of those who oppose it share the reason, even if they believe that other considerations may outweigh it. Note, that on this description there is no need to include John in the story. ${ }^{7}$

\footnotetext{
${ }^{6}$ Or, put differently, being reasonable might be conditional on accepting that his way of life is valuable (Tahzib, 2019).

7 See for instance (Laborde, 2017, 99).
} 
However, there has not been enough precision about reasonableness. Mang (2013, 302-3), for instance, argues that it should be accepted 'beyond reasonable doubt' by all reasonable citizens that 'hard-drug addiction is harmful to most, if not all, people'. Billingham $(2017,97)$ understands this as an empirical claim, but it could also be understood as an epistemic claim such that 'it would be unreasonable to think that a life of drug addiction is good.'

But neither of these interpretations succeed in undermining Quong's antiperfectionism. Quong's argument does not rest on the claim that disagreement about the good is inherently foundational or that many people disagree about the disvalue of drug use. While reasonable disagreement is at the centre of political liberalism, this should not be taken as an empirical claim about actual societies. The relevant society, for Quong $(2011,139)$, is the idealised 'well-ordered society', where 'everyone accepts and knows that others accept the same conception of justice'; it is publicly known that the basic structure of society satisfies the conception; and citizens are prepared to 'propose and abide by fair terms provided others do likewise.' The consequence of this is that Quong's $(2011,143)$ theory 'does not aim to achieve public justification or normative stability in current liberal democratic societies'. Rather, the goal 'is to show that the kind of citizens who would be raised in a society wellordered by a liberal conception of justice could endorse and support their own liberal institutions and principles if those institutions and principles are justified in a way' (Quong, 2011, 158).

For Quong, it is the hypothetical citizens living in this well-ordered society that are owed justification. They are the justificatory constituency. 'Reasonable citizens' is a technical term, disconnected both from everyday language and the reasonableness of actual persons. Reasonable citizens, on Quong's view, adhere to a liberal conception of justice. They disagree about what this entails in every instance, but in this disagreement, they share the same values, such as freedom, equality, and fairness. However, reasonable citizens have competing views about the good. Hence, the state cannot permissibly appeal to reasons drawn from the good when justifying policy. As Vallier $(2017,183)$ puts it, Quong 'simply assumes that reasonable people endorse the liberal values out of which a conception of liberal justice is constructed,' but he does not 'assume as much common ground on matters concerning ultimate good.' Or, in Andrew Lister's $(2014,32)$ words, Quong's 'asymmetry between the right and the good... is definitional, a matter of construction rather than a discovery'.

Why is this relevant for the case at hand? It is relevant, because on Quong's view it is enough that someone could deny that drug addiction is bad while continuing to be a full member of the well-ordered society (Quong, 2021, 53; see also 2011, 157) - asymmetry 'between disputes about justice and the good life...[is] a philosophical claim, and not an empirical fact.'

Clearly, there exist reasonable views that would deny that drug addiction is bad, even if they are not widely held in most societies. On hedonist-utilitarian views, using drugs in an otherwise 'normal' life could be an excellent way of living. ${ }^{8}$ Just

\footnotetext{
${ }^{8}$ Perhaps, we do not even need to go as far as hedonist utilitarianism. For a recent discussion, see (Hart, 2021).
} 
as some utilitarians believe that Nozick's experience machine is preferable to the real world, they might reasonably say that a life of great pleasure derived from using drugs is one that can be justified - or even encouraged - from their point of view. ${ }^{9}$

Contrary to folk theories of drug addiction, there is empirical evidence that at least suggests that even on heroin, it is possible for some users to uphold a wellfunctioning life if they have the means to continue using the drug. ${ }^{10}$ Of course, I do not wish to suggest that this is common, but the mere possibility opens the door for a hedonist-utilitarian case for using heroin. Because, for these few users, such a life could be incredibly hedonist-utility maximising. If we turn to less harmful drugs, the case of course becomes even stronger, and is made compatible with a broader range of moral theories (Husak \& De Marneffe, 2005).

Hence, there is nothing absolutely wrong from all moral points of view with using drugs. This can be a good way of living, at least on some views. And for Quong to block moderate perfectionism, this is all that he needs to show.

\section{Moving Forward}

I have argued that local comparative judgements do not successfully ground moderate perfectionism. I have also argued that on many views of public justification, including Quong's, the fact that many, or most, reasonable citizens in the real world probably agree that drugs are harmful, or that there are good reasons to disvalue drug use, does nothing to undermine the commitment to antiperfectionism. Quong's argument depends only on how his idealised justificatory constituency is constructed.

Do we have good reason to accept this constituency as the right one? Billingham $(2017,99)$ points out that 'Quong offers surprisingly little justification for his definition of the constituency.' Consequently, Quong's strategy leaves it open for perfectionists to construct their own justificatory constituencies that share perfectionist values.

This possibility has recently been explored. Collis Tahzib $(2019,166)$ argues in favour of a justificatory constituency according to which 'reasonableness is conditional on acceptance not just of liberal axioms (namely, freedom, fairness, and equality) but also perfectionist axioms (namely, moral, intellectual, and artistic excellence).' Without necessarily endorsing the position himself, Billingham (2017, 99-105) similarly shows that one could construct a justificatory constituency that accepts Mang's qualified perfectionist judgements or Chan's 'uncontroversial' perfectionist goods.

To accept that Quong's answer to the moderate perfectionist challenge is convincing, we would also have to accept that his characterisation of the justificatory constituency is superior to the alternatives. This might be difficult to do for someone who shares Chan's or Mang's view that it would be unreasonable (however

\footnotetext{
9 See for instance (Tännsjö, 2007, 95); for the same point, see (Quong, 2021, 53).

10 E.g. (Agar \& Reisinger, 2001; Draus et al., 2010; Pierce, 1999). For an early exploration of this idea, see (Caplovitz, 1976); and for the classic statement, see (Zinberg, 1984).
} 
understood) to deny that the life of most - if not all - drug addicts are not worthwhile. Anyone who accepts that might be drawn to a perfectionist idealised constituency who shares this concern (or other perfectionist goods). ${ }^{11}$

At the same time, we know that antiperfectionist political liberals like Quong would not accept this revised constituency, because it includes judgements about the good - something that they explicitly want to avoid. Which justificatory constituency that succeeds depends on accepting the validity of the broader theories.

Settling the question, thus, turns on political liberals or moderate perfectionists convincing their opponents that their favoured construction of the justificatory constituency is superior. Merely appealing to intuitions about reasonableness is no longer enough.

Acknowledgements I would like to thank Paul Billingham, Elsa Kugelberg, Cécile Laborde, Sune Lægaard, David Miller, Hallvard Sandven, Zofia Stemplowska, Collis Tahzib, Anthony Taylor, Stuart White, and the audiences at the Nordic Network in Political Theory, University of Oslo, and Owipt, University of Oxford, for helpful comments and discussions.

Open Access This article is licensed under a Creative Commons Attribution 4.0 International License, which permits use, sharing, adaptation, distribution and reproduction in any medium or format, as long as you give appropriate credit to the original author(s) and the source, provide a link to the Creative Commons licence, and indicate if changes were made. The images or other third party material in this article are included in the article's Creative Commons licence, unless indicated otherwise in a credit line to the material. If material is not included in the article's Creative Commons licence and your intended use is not permitted by statutory regulation or exceeds the permitted use, you will need to obtain permission directly from the copyright holder. To view a copy of this licence, visit http://creativecommons.org/licen ses/by/4.0/.

\section{References}

Agar, M., \& Reisinger, H. S. (2001). Open marginality: Heroin epidemics in different groups. Journal of Drug Issues, 31(3), 729-746.

Billingham, P. (2017). Liberal perfectionism and Quong's internal conception of political liberalism. Social Theory and Practice, 43(1), 79-106.

Boettcher, J. W. (2004). What is reasonableness? Philosophy \& Social Criticism, 30(5-6), 597-621.

Boettcher, J. W. (2019). Diversity, toleration and recent social contract theory. Philosophy \& Social Criticism, 45(5), 539-554.

Caplovitz, D. (1976). The working addict. Journal of Psychedelic Drugs, 8(4), 313-316.

Chan, J. (2000). Legitimacy, unanimity, and perfectionism. Philosophy \& Public Affairs, 29(1), 5-42.

Draus, P. J., Roddy, J., \& Greenwald, M. (2010). I always kept a job: Income generation, heroin use and economic uncertainty in 21st century Detroit. Journal of Drug Issues, 40(4), 841-869.

Fowler, T., \& Stemplowska, Z. (2015). The asymmetry objection rides again: On the nature and significance of justificatory disagreement. Journal of Applied Philosophy, 32, 133-146.

Hart, C. L. (2021). Drug use for grown-ups: Chasing liberty in the land of fear. Penguin Press.

Husak, D., \& De Marneffe, P. (2005). The legalization of drugs (pp. 184-185). Cambridge University Press.

\footnotetext{
$\overline{{ }^{11} \text { In a response paper, Quong }}(2014 \mathrm{~b}, 101)$ concedes that he does not have a 'very well developed objection' to a public reason theory with a perfectionist justificatory constituency. Another available option is to leave the question of the permissibility of perfectionism underspecified by basing the justificatory constituency on real citizens. I pursue this approach in (Kugelberg, 2021).
} 
Kugelberg, H. D. (2021). Civic equality as a democratic basis for public reason. Critical Review of International Social and Political Philosophy. https://doi.org/10.1080/13698230.2021.1905468.

Laborde, C. (2017). Liberalism's religion. Harvard University Press.

Laycock, J. P. (2020). Speak of the devil. Oxford University Press.

Lister, A. (2014). Public reason and perfectionism: Comments on Quong's liberalism without perfection. Filozofija i društvo, 25(1), 12-34.

Lister, A. (2018). The coherence of public reason. Journal of Moral Philosophy, 15(1), 64-84.

Mang, F. F. L. (2013). Liberal neutrality and moderate perfectionism. Res Publica, 19(4), 297-315.

Pierce, T. G. (1999). Gen-X junkie: Ethnographic research with young white heroin users in Washington, DC. Substance Use \& Misuse, 34(14), 2095-2114.

Quong, J. (2011). Liberalism without perfection. Oxford University Press.

Quong, J. (2014a). What is the point of public reason? Philosophical Studies, 170, 545-533.

Quong, J. (2014b). Liberalism without perfection: Replies to Lister, Kulenović, Zoffoli, Zelić, and Baccarini. Philosophy and Society, 25(1), 96-122.

Quong, J. (2021). On Laborde's liberalism. Criminal Law and Philosophy, 15, 47-59.

Schouten, G. (2019). Liberalism, neutrality, and the gendered division of labor. Oxford University Press. Tahzib, C. (2019). Perfectionism: Political not metaphysical. Philosophy \& Public Affairs, 47, 144-178.

Tännsjö, T. (2007). Narrow hedonism. Journal of Happiness Studies, 8(1), 79-98.

Vallier, K. (2017). On Jonathan Quong's sectarian political liberalism. Criminal Law and Philosophy, 11(1), 175-194.

Watson, L., \& Hartley, C. (2018). Equal citizenship and public reason: A feminist political liberalism. Oxford University Press.

Zinberg, N. E. (1984). Drug, set, and setting: The basis for controlled intoxicant use. Yale University Press.

Publisher's Note Springer Nature remains neutral with regard to jurisdictional claims in published maps and institutional affiliations. 